\title{
Students' Classroom Interaction in Speaking English at Fourth Semester in University of Graha Nusantara Padangsidimpuan
}

\author{
By: \\ Nusaima Harahap, Rini Kesuma Siregar, Yulia Rizki Ramadhani \\ Department of English Education, University of Graha Nusantara \\ Padangsidimpuan
}

\begin{abstract}
Abstrak. Tujuan dari penelitian ini adalah untuk mengetahui interaksi kelas siswa dalam berbicara Bahasa Inggris pada semester empat Universitas Graha Nusantara Padangsidimpuan; untuk mengetahui interaksi kelas siswa dengan dosen dalam berbicara bahasa Inggris pada semester empat Universitas Graha Nusantara dan untuk mengetahui kesulitan dan upaya penyelesaian terhadap interaksi kelas siswa dalam berbicara bahasa Inggris pada semester empat di Universitas Graha Nusantara Padangsidimpuan. Penelitian ini menggunakan penelitian kualitatif dengan metode deskriptif. Setelah mengumpulkan data, peneliti menganalisis data dengan menggunakan reduksi, kemudian membagi data dengan mengkategorikannya. Setelah itu, peneliti membuat interprestasi dan mendeskripsikan data untuk menarik kesimpulan. Peneliti menemukan fenomena interaksi kelas siswa dalam berbahasa Inggris pada semester empat Universitas Graha Nusantara Padangsidimpuan berjalan dengan baik. Beberapa siswa dapat berbicara bahasa Inggris di kelas. Beberapa diantaranya, sekitar 15 siswa dapat berbicara bahasa Inggris. Interaksi kelas siswa dengan dosen dalam berbahasa Inggris di semester empat Universitas Graha Nusantara Padangsidimpuan juga berjalan dengan baik. Mereka dapat memberikan umpan balik untuk menanggapi dosen. Kemudian siswa juga menggunakan bahasa Inggris dalam berdiskusi, presentasi, dan bertanya kepada dosen. Kesulitan dalam interaksi kelas siswa berbahasa Inggris adalah kurangnya kosakata, kesalahan dalam pengucapannya, kurangnya percaya diri, kurangnya latihan, dan tidak menguasai materi bahasa Inggris.
\end{abstract}

\begin{abstract}
The purpose of the research is to know Students' classroom interaction in English speaking at fourth semester in University of Graha Nusantara Padangsidimpuan; Students' classroom interaction with lecturer in English speaking at four semester in University of Graha Nusantara, and to know the difficulties and effort to solve it of students' classroom interaction in English speaking at on the fourth semester in University of Graha Nusantara Padangsidimpuan. This research used qualitative research with descriptive method. After collecting data, the researcher analyzed the data by using reduction, then devided the data to one unit with categorize the data. Afterwards, the researcher made interprestation and described about data to make a conclusion. The reseacher found phenomena Students' classroom interaction in English speaking at four semester University of Graha Nusantara Padangsidimpuan was running well. Some of students could speak English in classroom. Some of them its means about 15 students could speak English to others. Students' classroom interaction with lecturer in English speaking at fourth semester University of Graha Nusantara Padangsidimpuan was also running well. They could give feedback to lecturers' respond. Then they used English for discussion, presentation, and asking to lecturers. The difficulties of students' classroom interaction in English speaking were in lack of vocabulary, mistakes pronunciation, low self confidence, less practice, and did not master English material.
\end{abstract}

Keywords: Classroom Interaction, Language Classroom, English Classroom, Speaking English 


\section{INTRODUCTION}

Learning a foreign language is an integrated process that the learner should study the four basic skills: listening, speaking, reading, and writing. In language teaching, the four skills are described in term of their direction. Language generated by the learner (in speech or writing) is referred to as productive. Language directed by the learner (in reading and listening) is called receptive. Each of them are important and has the relation each other. Language teaching is a complex activity, and this complexity derives primarily from the diversity of perceptions and the goals of the various participants who play a role in the teaching. The process of learning is the most common element in the classroom.

In the classroom students do their educational activity - learning - but they also do another activity like playing and socializing with their friends. Classroom is a small miniature of wide society filled in with many elements. Classroom is a real social context where its elements (teacher and learner) enter into equally real social relationship each other, but, in the sense of education, it's an artificial environment for teaching, learning, and using a foreign language.

Language teaching, in a simple word, can be defined as the activities which are intended to complete language learning. It is assumed that language teaching is proposed to help people to learn and use the language.Classroom is not a place where the teacher just carries out predetermined routines, but rather than a place where various elements interact one another. These elements are the teacher with his educational background, the students, experience, knowledge, and expectation and also the activity in the classroom.

Language learning occurs through meaningful interaction. Interaction, then, will certainly involves students. In other words, it can be said that language learning is a two-way interaction between all the elements in class. Those elements handle the same significant role in deciding whether the learning will achieve its aim or not. Each element cannot dominate the others. The teacher, then, handles a significant role in creating an atmosphere that stimulates students to participate in the classroom. The teacher also has to plan certain activities and interactions in order to achieve or produce a particular behavioral outcome.

In the speaking classroom, the teacher and the students have significant roles to the process of teaching and learning. These elements (teacher and students) constantly interact one another in which the teacher and the students are the main subjects. In speaking class, the teacher is not allowed to dominate the class where he keeps talking or giving more question. Each element has as much to contribute 
as very other participant in determining the direction and outcome of the interaction.

From above the explanation, we know that interaction in the language classroom is very important in the process of teaching and learning. In the speaking english, how the teaching-learning process run well also depends on the interaction between the teacher and the students. Therefore, understanding the interaction happening in the speaking classroom is also very important.

According to Diah, a student on sixth Semester in Graha NusantaraUniversity Padangsidimpuan said the students do not interact well in English. They are still use mother tongue or Indonesian language in daily conversation. Then based on observation in the other class, the students use still Indonesian language to communicate with the lecturer and their friends whereas they are English students that should use English in their communication.

Based on the above description, the researcher is interested in study about the interaction in a language classroom forEnglish speakingStudents at fourth Semester in University of Graha Nusantara.

Classroom interaction is the activity of students with the teacher and their classmates. Interaction has a similar meaning in the classroom. We might define classroom interaction as a two way process between the participants in the learning process. Brown relates interaction to communication, saying, "...interaction is, in fact, the heart of communication; it is what communication is all about."

The researcher focuses on two types of interaction because the researcher only want to research in this limitation. Based on the research question before that there are two especially research questions of this research. It is caused the important elements of the classroom is lecturer and learners.

Classroom interaction aims at meaningful communication among the students in their target language, it also aims at probing into the learner's prior learning ability and his way of conceptualizing fact and ideas. The term Classroom Interactionrefers to the interaction between teachers and learners in the classroom. Foreign language classroom interaction research begins in 1960s with the aim of evaluating the effectiveness of language acquisition. Interaction is at the heart of communicative competence. 
H. Douglas Brown said that "speaking is personality factor is an important aspect of carrying on discourse another factor is feeling ashamed. The students afraid to express their ideas. They worried everyone will mock them. External factors come out from the students". Speaking is an essential tool communicating, thinking and learning, oral language. Oral language is a foundation or all language development and therefore the foundation of all learning.

Based on above the explanation, the researcher concludes that speaking is an activity to express what we feel, see, think, and what we want to say. Speaking interaction occurs between speaker and listener that convey the message from a speaker to listener.

In classroom interaction the teacher had dominant role of an all-knowing leader who filled students' empty head with knowledege. This role has changed and the teacher has many roles depending on different situation interactions. In a board sense, he is a facilitator of learning which includes the following:

a. A general overseer of learning, who coordinates the activities so that they form a coherent progression from lesser to greater communicative ability.

b. A classroom manager, who is responsible for grouping activities into lesson and for their overall organization.

c. A language instructor, who present new language, controls, evaluates and corrects learners' performance.

d. In free communicative activities, the teacher will act as a consultant or adviser , helping where necessary. The teacher may move around the classroom and monitor students' progress, strengths and weaknesses.

e. Sometimes the teacher will participate in an activity as a co-comunicator with the learners. The teacher may encourage learners without taking their main role.

The purpose of the research generally is to know students' classroom interaction in English speaking at fourth semester in University of Graha Nusantara and especially purposes of this research are to know: 1) Students' classroom interaction in English speakingat fourth semester in University of Graha NusantaraPadangsidimpuan; 2) Students' classroom interaction with lecturer in English speaking at fourth semester in University of Graha Nusantara The difficulties and effort to solve it of students' classroom interaction in English speaking at on the fourth semester in University of Graha Nusantara Padangsidimpuan. 


\section{METHOD}

Based on the analysis of data, this research used qualitative research with descriptive method. The sources of data for this research are:

1. The primary sources of data were students at fourth semester and the English lecturers in University of Graha Nusantara Padangsidimpuan. Fourth semester was chosen by researcher because in this class, students' speaking ability at fourth semester is lower than the other class. The researcher took 12 students to be interviewed. They were selected through specific character to represent all students at english department in UGN Padangsidimpuan.The specific characters are12 students have different IPK. The researcher interviewed 4 students that have high IPK, 4 students that have low IPK and 4 students that have average IPK. It is regarded can represent all of students at fourth semester.

Then the researcher interviewed 3 lecturers of english department in University of Graha Nusantara Padangsidimpuan. They are Ms Mahrani, M.Hum and Mrs. Siti Meutia.M. Hum. They taught Introduction to linguistic, Cross Culture Understanding, Morphology and Speaking subjects. The researcher only interviewed 2 lecturers because they are the lecturers who almost speak English fully in classroom.Then in their class, classroom interaction in English speaking occurs because of they ask to speak English to students and related to English speaking.

This research used purposive sampling. Students at fourth semester are lower in English speaking ability than the other classes. It made the researcher was interested to do research how classroom interaction in English speaking at fourth semester.

The researcher used observation and interview to collect data. The researcher collected data by descriptive method and it is necessary to get the researcher involved as the object of the research directly, because in qualitative research, the researcher is the real instrument.

2. The secondary sources of data were gained from the english lecturers in University of Graha Nusantara Padangsidimpuan. Considering interview needs many times, the other lecturers can give additional information about classroom interaction.

The researcher used observation and interview to collect data. The researcher collected data by descriptive method and it is necessary to get the researcher 
involved as the object of the research directly, because in qualitative research, the researcher is the real instrument.

In research, after collecting data, the researcher analyzed the data. The technique of data analysis will be presented in descriptive form. According Lexy J. Moleong that technique of data analysis in qualitative research can be done with these process below:

1. Starting from research about all data which consist of some sources data.

2. Holding reducation of data with making abstraction.

3. Arranging in one unit.

4. Categorization to the next steps.

5. Holding investigation about validity of data.

6. Making interprestation of data.

So, from above the explanation, the reseacher analyzed data by using reduction, then devided the data to one unit with categorize the data. Afterwards, the researcher madeinterprestation and described about data to make a conclusion.

Trustworthiness in qualitative research is very important because checking to the trustworthiness of the data is used to contradicted the assumption of qualitative research is not scientific. To reduce the bias of the data and to improve the validity of the data collected according to Lexy J. Moleong, they are:

1. The extension of participation is the extention not only done at the short time, but need the long time.

2. The application of research is the research must do the research with careful, detail and continuous to the object of the research.

3. Triangulation is the technique of checking data trustworthiness that using something beside the data no verification or as a comparison of the data.

4. Checking with friendly through discussion is done with expos the interview result of the final result that gotten in discussion with friends.

5. Analyze the negative case is the research collects the example an inappropiate case with the modal and the inclination of information that have coolected a used as a substance of comparison.

6. The adequate and referential are the tools of them, which using the free time, which using the free time to compare the result of the research with critics were collected.

7. Checking the member is the most important in checking the credibility.

8. The detail description is a technique to demand the researcher to the result his/her research. 
9. Auditing used to check the truth and certainly of data, this point that done well to the process or result and extent.

From above the explanation, the researcher used point 4 for this research. It is checking with friends through discussion is done with expos the interview result of the final result that gotten in discussion with friends. The researcher asked to Ms. Yulia Rizki Ramadhani and Ms. Rini Kesuma Siregar

\section{RESULTS AND DISCUSSIONS}

Description of Students' Classroom Interaction in English Speaking at IV Semester in University of Graha Nusantara Padangsidimpuan

Classroom interaction is the action performed by the lecturer and the students during instruction interrelated. Classroom is occurred everyday in the class between the lecturer and the students. They interact for some reasons such as get information, asking something, to teaching learning or just keep relationship with friends.

The researcher have analyzed students' classroom interaction in English speaking at fourth semester in University of Graha Nusantara Padangsidimpuan by data collecting with observation and interview. The observation have done in Ms Mahrani's class and Mrs.Siti Meutia's class. Then the researcher have interviewed 12 students and 2 lecturers in English Education Department (PBI). The result as follows:

\section{Observation}

Based on the observation students' classroom interaction in English speaking at IV semester in University of Graha NusantaraPadangsidimpuan was running well. While the lecturer explained about the lesson, they look like understand and gave respon the lecturer altoughit was some of them. But most of students just kept silent when lecturer asks them did they understand with the lesson. The lecturer's question was anwered by students around 6 students. Interaction between or among students in the classroom occurs but it is still under the control of the lecturer.

The students still usedIndonesian language for respon the lecturer instruction or questions. Moreover, they spoke ethnic language in classroom with their friends, whereas they are English students who exist in education environment. They should usedEnglish or Indonesian language minimal. 


\section{Interview}

After interviewing the participants, the researcher found that students' classroom interaction in English speaking atIV semester in University of Graha NusantaraPadangsidimpuan used English in class sometimes.

Informant Ayu Andira said they used English but in formal situation they also used Indonesian language. Then informant Ayu Sri Andari and Feni stated that communication in English was rare used in classroom. They used English only for discussion in learning. In classroom they used Indonesian language too much, moreover they used Mandailing language sometimes in classroom. Rizky Akbar and Lanni stated that they used English in classroom only when there are lecturers there. It means English is used for learning process.

Next Arfinuddin and Elfrida stated that they speak English sometimes although there was no feedback when they speak for sometimes. Their friends responded them in Indonesian language. Even when they speak English in classroom, their friends called they were pedantry. Last informant Megawati stated that there were $40 \%$ students could interact in English and $60 \%$ could not.

For informant Ade Purnama, She stated that students' classroom interaction in English speaking at their class was good enough. It was because from the second semester up to now had differences. Their interaction in English had much progressed. One of lacking in their class in was less practice. The practice like they used to do. The lecturers have to order them to speak English then they would. There was no awareness from the students to speak English.

According to the informants, half of them stated that they used English sometimes. They used English only for learning process, discussion, and speak to lecturers. Then they more often used Indonesian language although in classroom. The students IV semester interact to their friends in Indonesian language. But actually, they should used English because they were English students. It could help to increase their speaking in English and would create feedback among them.

In serious condition, they still used ethnic language such as Mandailing and batak language in classroom. Besides they were in education environment. It was an obligation to used Indonesian language in education environment even though outside of classroom. The students' interaction in English appeared only when they had a discussion activity with their group in classroom. 
So, from the above explanation the researcher conclude that students' classroom interaction in English speaking at fourth semester in University of Graha NusantaraPadangsidimpuan was running well. They sometimes use English in classroom. Then they used Indonesian more often language than English in classroom. They interacted to their friends did not used English, but used Indonesian language. Moreover, they still used mother tongue or ethnic language in classroom.

\section{Description of Students' Classroom Interaction with Lecturer in English Speaking at IV Semester in University of Graha Nusantara Padangsidimpuan}

Students' classroom interaction with lecturer in English speaking at IV semester in University of Graha NusantaraPadangsidimpuan was still lecturers' dominant. It was just like typical classroom interaction in Indonesia. Lecturers had done the best teaching and speak English in classroom. From beginning up to the end entered to the classroom, lecturers almost used English fully.

Students' classroom interaction with lecturer in English speaking at IV semester in University of Graha Nusantara Padangsidimpuancan be seen through observation and interview. From the observation and interview result, the researcher found students' classroom interaction with lecturerin English speaking at IV semester in University of Graha Nusantara Padangsidimpuan occurred well.

\section{Observation}

Some of students could respond the lecturers' question or lecturers' statement. They gave feedback to lecturer in English. Interaction occurs between speaker and listener that convey the message from a speaker to listener. In classroom IV semester, students sometimes speak English although to lecturer. Some of students are unresponsive that make the lecturerfrustased. The unresponsive of the students definitely causes no interaction in classroom. While observation, most of students did not attend the lecturer, moreover there was student who played laptop and open Facebook. She was not care about existence of the lecturer and the lesson. Afterward, the other students, generally get seat in back, played the hand phone while learning process. They did not listen what the lecturer say. Finally, they did not understand about the lesson for English, we give attention fully, it was not sure we would understand, even less we did not.

From the observation result, the researcher saw some of students prefer asked to their friend compare with ask to lecturer directly. Then they prefer like keeping 
silence rather than speak in English. They thought it was better than spoke English but made mistake in sentence grammar.

In this class, the lecturer took almost $80 \%$ in English speaking. The students only listen and do what the lecturer instruct them. In other word, there is no interaction in English without lecturers in classroom.

\section{Interview}

Diah and Veronica stated that they always speak English to their lecturer, especially in classroom. Uchi stated that they often use English with lecturers in classroom. They speak English for learning process and other situation with lecturer. But Leli Mahrani, Rifai and Novri Adelina state they speak English sometimes with lecturers in classroom.

Then Rio and Asrani said that they spoke English depend to lecturers. They used English if the lecturer spoke English before. They used English when the lecturers require them to speak English. Last Dolly Parlindungan stated that classroom interaction with lecturer in English speaking will occur if the lecturers grow up English interaction before. They look like had not awareness to start speak English before lecturer. They only follow what the lecturer did.

According to Mrs. Siti Meutia, English language interaction in classroom was not good enough. It was because while teaching he could hear still students mostly speak Indonesian and even ethnic language rather than English. Then students speak English was not really well. Students have no desire to improve their speaking skill.

Mrs. Siti Meutia stated that he always spoke English while teaching in classroom. The responses of students was variety such as some of students response in English and another was not, then some of students looked like understand and another was not, last some of students did through the instruction some did not. But actually, Mrs. Siti Meutia asked students to speak English in classroom.

They did not have awareness to apply what the lecturer asked for them. They had fear in themselves to speak in English. They did not have a brave to practice. They were afraid to make mistake and their friends would mock them.

Next according Ms.Mahrani, she stated that students' classroom interaction in English speaking for fourth semester was not significant for every student, but for some of them was significant. Their interaction was good. But it was only some of 
them, not dominant. There were around 20\% for all students interacted in English with her of fourth semester.

Same to Mrs. Siti Meutia , Ms.Mahrani also she always asked students to speak English in classroom while teaching. For example in opening discussion and giving question. She ordered them to speak in English, but when they still difficult and think really hard to say, she gave them help to clarify the sentence in a good sentence. But so far, they still hard in speak in English fully.

About the students' responses, she stated that students who understand about her language and interesting in English, they still good speak in English. But some of students looked confuse. Then Ms.Mahrani would make clear her statement or explanation to students. However, there were students was still confused, she took the last choice, it was speaking Indonesian language to them.

From the observation and interview result, the researcher concluded that students' classroom interaction with lecturer in English speaking at VI semester in University of Graha Nusantara Padangsidimpuan was running well. Most of students gave respond back the lecturer question or statement. But it was only if lecturer order to students to speak English and would punishment to students who did not speak English.

\section{The Difficulties and Effort to Solve it of Students' Classroom Interaction in English Speaking at IV semester University of Graha Nusantara Padangsidimpuan.}

English is international language. Since many years ago English is taught as a foreign language in non-native English countries, belong Indonesia. The main purpose is to obtain education quality to improve human resources. The teaching of English in school therefore is to meet the people need of the non-native English countries that is to able to use English as medium of worldwide communication.

In fact, there was thinkingthat English is difficult. But it was only for some of students. After interviewing, the researcher found the variety of reasons why they thought English is difficult.Marhamah, Darwis simbolon,Anggi Husnasaid that the difficulties in English were in lack of vocabulary, mistakespronunciation, low self confidence, less practice and did not master English material. They sometimes did not know how to pronounce the word in English. So it made they do not have motivation to speak English. 
Then Linda simanjuntak, Vero and Pernando stated that English is difficult because did not master in grammar and structure. Then they were shy to speak English. It was because sometime when they spoke English their friends would give feedback in Indonesian. So they also spoke Indonesian to the next conversation.

Duma sari and Rifaistated that the difficulty in English is practice. Then the other difficulties are situation and condition. It did not support fully for him to speak English. Sometime he speaks English to his friend, but his friends did not answer in English. It made him to be lazy to speak English.

Ms.Mahrani stated that the difficulties in English speaking weremost students did not know the elements of language like word, phrase, sentences. Then most of students did not know how to choose the appropiate word in the sentence of English, and most of students did not how know to choose the appropiate phrase in the sentences of English. Afterward most of students still did not know how to construct based the sentence of English based on the context of speaking beside they do not know the grammar and the structure of the sentence. The last they were harden to practice in English in speaking.

Then Mrs Siti Meutia said that the difficulties in Englishspeaking were in English materials. They did not master the materials for English. In spite of he had many techniques to help for teaching them, but the materials in English was the main point. Mrs Siti Meutia also told that they must master all the materials in English start from meaning, structuring, and questioning. The system was said the system of meaning in mind, the system of construction such as lexicogrammar, the word in morphology, and sentence in syntax and lexicogrammar. So the important thing was material.

Every problem has the solving. The effort to solve the difficulties of students' classroom interaction in English speaking at IV Semester in University of Graha Nusantara Padangsidimpuan was various. Jumaida said that she try to did practice more often than usually. Nandasaid that she added new vocabulary to enrich her vocabulary.

Then Diah and Anggi Zuhro also state that they had effort to sole the difficulties were enrich vocabulary and often read the text book. Next Farida had effort was try to interact to the other in English.Johannes and Rifky have effort to solve the difficulties in English speaking. That is speaking English to the other although out 
of classThen Gita Sri jayanti had different effort form the usually. She tried to speak English although at boarding house. They committo speak English and give fine who broke the commitment.

The effort did not only comefrom students just, but the lecturers also had the effort. Ms Mahrani had effort such as did the lesson in the class in English from beginning up to the end of the class, communicated with students in English, did the interaction in English, askstudents' responses in English, encourage students to speak English all the time.

Mrs Siti Meutia had the different effort. He tried to grow up the students' self confidence. As long as they understand about what he said, the students could make mistakes in English speaking. Mrs Siti Meutia did not require the students have to speak based on structure and grammar. It was useful to grow students' self confidence up.

From the explanation above, the researcher concluded thing made students thought English is difficult were lack of vocabulary, less confidence, less practice, hard in grammar and structure, and they did not master the material. This was the general problem in English class. For solving the problem, students and lecturers had the effort to improve classroom interaction in English speaking.

Classroom interaction is the activity of students with the teacher and their classmates. Action and reaction are two inseparable activities shown in interaction. But action and reaction are nothing to do with interaction if they do not show reciprocation.Interaction in the classroom is fundamental, because without it teaching learning process in the class will be not exit. A good interaction will make message transmission success and create a good interpersonal relationship between the lecturer and the students. So the students' achievement in language acquisition can be increased.

As mentioned before, Larazaton someone could be said speaking well when he had 4 competences, they are grammatical, sociolinguistics, discource, and strategic competences. Then according to Arthur, there are categories to measure speaking skill, they are accent, grammar, vocabulary, fluency, and comprehension. So, for this class only some of elements that could they well to do. 
Students' classroom interaction in English speaking at IV semester University of Graha Nusantara Padangsidimpuan generally was running well. Some of them could respond back the interaction of their friends and lecturers. To anticipate this situation, they needed the solutions from themselves and lecturer. The solutions were given by the lecturers were speaking English fully while teaching and asking to students to speak English in classroom. Then the solutions from the students were learn vocabulary and learn by heart it, felt curious to new word in daily activity and so on. Moreover there was a student who made commitment to speak English although in boarding house. It was a good step to improve her English speaking.

Mrs. Siti Meutia statement about things made students thought English is difficult was the material. For example part of speech. It was English material. The students would harden if they could not master in the material. Same to the students at fourth semester, one factor made students' classroom interaction in English speaking was still low was in material.

\section{CONCLUSIONS AND SUGGESTIONS}

After treating the collecting data, the next steps were taking the conclusions of this research. It is regarded important because it can be describe the final research itself. The conclusions of this research as following:

1. Students' classroom interaction in English speaking at fourth semester University of Graha Nusantara Padangsidimpuan was running well. Some of students could speak English in classroom. Some of them its means about 15 students could speak English to others.

2. Students' classroom interaction with lecturer in English speaking at fourth semester University of Graha NusantaraPadangsidimpuan was also running well. They could give feedback to lecturers' respond. Then they used English for discussion, presentation, and asking to lecturers.

3. The difficulties of students' classroom interaction in English speaking were in lack of vocabulary, mistakes pronunciation, low self confidence, less practice, and did not master English material and the efforts to solve it of students and English lecturer in improving classroom interaction in English speaking were:

a. Students enrich their vocabulary in English and often reading English book.

b. Students interact to others in English although out of class. 
c. Made commitment to speak English in boarding house.

d. The lecturers ask to students to speak English fully in classroom.

e. Growing up the students' self confidence to speak English although they make mistake to English speaking.

After formulating the conclusions, the researcher wants to give the suggestions concern with the result of the research. It can be seen as follows:

1. The researcher on this occasion hopes that other researcher will conduct a research related to the topic of this study, especially to find out other students' classroom interaction in English speaking.

2. To the Leader ofUniversity of Graha NusantaraPadangsidimpuan to support the lecturers in teaching well and provide facilities involves with learning process such as renovate language laboratory and make it more complete and comfortable for students.

3. To the Chief of English Education DepartmentUniversity of Graha Nusantara to make English area for students to increase their ability in English speaking and improve their accent and pronunciation.

4. To the English lecturers were hoped to more active in motivate students for English speaking practice in classroom and in campus area.

5. To the English students were hoped to increase their frequency in speaking and often practice in English speaking.

6. It is important to the other researcher to make the deepest research with this topic because it is still far from the perfect one to topic to the limitation of the researcher material, knowledge and experiences.

\section{REFERENCES}

Brown, H. Douglas. (2001). Principle Of Language Learning and Teaching. New Jersey: Prentice Hall.

Brown, H. Douglas. (2004). Language Assessment: Principle and Classroom Practice. San Fransisco: Longman.

Creswell, Jhon W. (2003). Research Design: Qualitative, Quantitative, and Mixed Methods Approaches. New delhi: Sagc Publications, inc.

Cyril J. Weir. (1990). Communicative Language Testing. USA: Prentice Hall.

Dagarin, Mateja. (2004). Classroom Interaction and Communication Strategies in Learning English as a Foreign. Elope. English Language Overseas Perspective and Enquires. Vol. 1/1-2: University of Ljubljana.

Ellis, R. (2001). Form-focused Instruction and Second Language Learning. Malden, MA : Blackwell Publisher.

Gay, L. R. and Airasian, Peter. (2000). Educational Research: Competencies for Analysis and Application. USA : New Jersey.

Hargie, O., Saunders, C \& Dickson, D. (Eds). (2006). Social Skills in Interpersonal Communication. London and Camberry: Croom Helm. 
Hornby, A. S. (2010). Advanced Learners Dictionary Current English (8th Edition). London: Oxford University.

Hudges, Arthur. (2003). Testing for Language Teacher. Australia : Cambridge University Press.

Jack, c. \& willy. A. (2002). Methodology in Language Teaching. America: Cambridge University Press.

Jackson, Howard and Ze' Amvela, Etienne. (2007). Words Meaning and Vocabulary. London : Cassess.

Lazaraton, A. (2001). Teaching oral skills, in m. Celce-Murcia (ed), Teaching English as A Second Language. Boston: Heinle and Heinle.

Long, Michael, and Porter, Patricia. (1985). Group Work, Interlanguage Talk, and Second Language Acquisition. TESOL Quarterly 19(2).

Luu Trong Tuan and Nguyen Thi Kim Nhu. (2010). Theoritical Review on Oral Interaction in EFL Classrooms, in Journal Studies in Literature and Language, Volume 1, No. 4, p. 30-35.

Nunan, David. (1991). Language Teaching Methodology: A Text Book for Teachers. Hemel Hempstead: Prentice Hall.

Nunan, David. (2003). Practical English Language Teaching. New York : McGraw-Hill Companies.

Phill whitmer. (2015). Classroom Interaction. Available : http://www.answerbag.com [17th December 2017]

Reza Kalantari. (2009). Techniques for Classroom Interaction" International Journal of Language Studies, Vol.3 (4). Available : http//www.asionefl.journal.com [17th December 2017].

Ricards, Jack. C. and Renandya, willy A. (2002). Methodology in Language Teaching. New York: Cambridge University Press.

Tarigan, Hendri Guntur. (2015). Berbicara Sebagai Suatu Keterampilan Berbahasa. Bandung: Angkasa. 